\title{
MODELLING OF CLIMATE GHANGE MITIGATION POLICIES ON NATIONAL SCALE
}

\author{
I. OKHREMCHUCK, PhD student* \\ Lviv Polytechnic National University \\ E-mail: inna.a.okhremchuk@|pnu.ua
}

The Kyoto Protocol, Paris agreement, concept of sustainable development are designed to solve global environmental problem and to limit the increase in global temperature to no more than 1.5 to 2 degrees Celsius. Integrated assessment models use IPCC scenarios to forecast future greenhouse gas emissions, choose policies and regimes for greenhouse gas reduction in certain sector, analyze how greenhouse gas emissions will influence on different ecosystems, people's health and states' economy. Ecological security make directly influence on national security. If the world community will not solve the issue of global climate change, then the number of natural hazards will lead to a rise in poverty, armed conflicts, food shortages, rising numbers of refugees, etc. However, it is necessary to analyze and indicate countries' capacity to implement climate mitigation policies successfully, because corrupt, undemocratic with self-surviving values and unequal rights country has low possibilities to provide a successful implementation of climate mitigation policies

Ключові слова: IPCC scenarios, The Kyoto Protocol, Paris agreement, Sustainable Development, implementation of the climate change mitigation policies, Integrated Assessment Models (IAM), climate change mitigation policies

Introduction. Global environmental problem is a great challenge for international society. The Kyoto Protocol and Paris agreement are the result of cooperation between governmental leaders and scientists in limiting the increase in global temperature by the end of this century to no more than 1.5 to 2 degrees Celsius by dint of reduction of greenhouse gas emissions and developing renewable source of energy. [11] It leads to creating new committee and energy strategies, forming system of penalties and incentives (e.g. carbon tax, subsidies) on national levels. Due to those agreements, countries have quotas on greenhouse gas emissions. However, different countries have different possibilities for modernizing and their sustainable development. It is necessary to analyze and indicate countries' capacity, problem sides and to give recommendation for successful policies implementation.

1. The concept of sustainable development

In September 2015 on United Nations (UN) summit, the Heads of State and Government and High Representatives set the 17 Sustainable Development Goals (SDGs), which were indicated and detailed in Resolution "Transforming our world: the 2030 Agenda for Sustainable Development" by The General Assembly of UN.[10] On 1 January 2016 the SDGs officially came into force. It means, that all countries during their development should find a balance

*Supervisor Mykola Gusti - Ph.D., Senior Researcher at the Department of International Information 


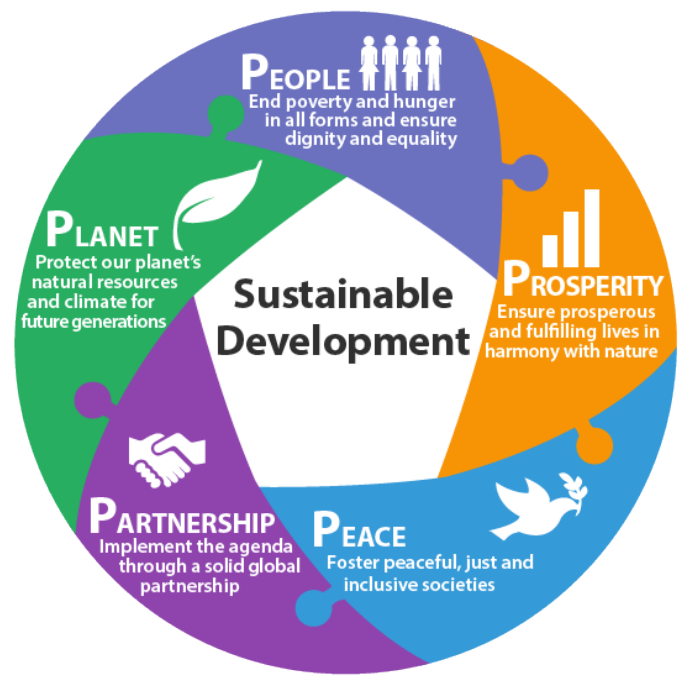

Fig. 1. Three dimensions of sustainable development [14]

between three dimensions: economic, social and environmental (see Fig.1). [13]

Ecological security is an important part of sustainable development and countries' prosperous future. [13] Solving of global environmental problems require system approach, accurate estimates and prognosis. A common methods are building scenarios and their estimation using mathematical models.

\section{Scenario and Integrated Assessment Models}

Intergovernmental Panel on Climate Change (IPCC) developed the Shared Socioeconomic Pathways (SSPs), the Representative Concentration Pathways (RCPs) and the Representative Concentration Pathways (RCPs), which contain various scenarios. The input data for SSPs are population, gross domestic product, urbanization trajectories, qualitative assumptions on the energy and land use sector. The RCPs define radiative forcing, that are used for modelling of climate change (how it would change in accordance with the SSPs and what steps should be made for achieving a certain level of antrophogenic influence on the climate). The SPAs contain information about policies and regimes for greenhouse gas reduc- tion in certain sector. RCPs, SSPs and SPAs are used in different combinations. [7]

There are five SSP scenarios: SSP1 (Low challenges) - Sustainability, SSP2 (Intermediate Challenges) - Middle of the road,SSP3(Highchallenges)-Fragmentation, SSP4 (Adaptation challenges dominate) Inequality, SSP5 (Mitigation challenges dominate) - Conventional Development) (Fig. 2).

One of the best tools for scenarios and policies analysis is an Integrated Assessment Models (IAM), which include knowledge from different fields of knowledge. For SSPs analyses are used different IAMs:

SSP1: IMAGE - PBL Netherlands Environmental Assessment Agency;

SSP2: MESSAGE-GLOBIOM

International Institute for Applied Systems Analysis (IIASA);

SSP3: AIM - National Institute for Environmental Studies (NIES);

SSP4: GCAM - Pacific Northwest National Laboratory (PNNL);

SSP5: REMIND-MAGPIE-Potsdam Institute for Climate Impact Research (PIK). [6]

However, implementation of the climate change mitigation policies still remains totally unpredictable. After analyzing of numerous reports on implementation of environmental programs in China, Indonesia, Ethiopia, Uganda, Mexico, Kenya, Republic of

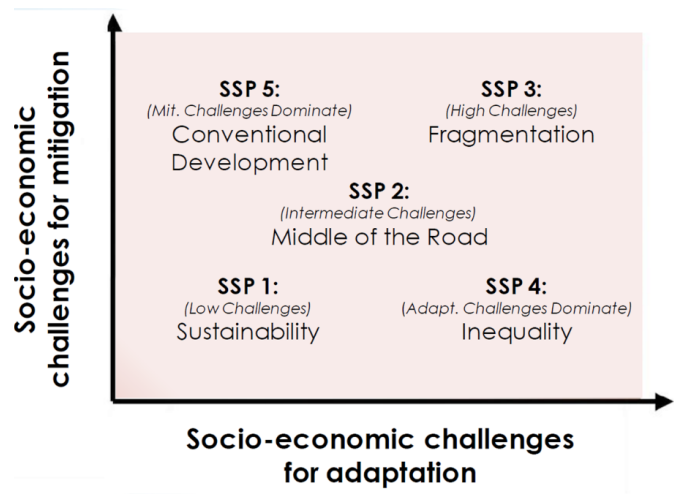

Fig. 2. The Shared Socioeconomic Pathways (SSPs) [3] 
Cameroon, Brazil and Bangladesh, it becomes clear that implementation of climate mitigation policies should be conducted together with socio-political improvements. Such factors as high level of corruption and poverty; low level of government effectiveness, rule of law, trust in government actions and law; unequal right, prevalence of survival values, geographical location, natural disasters, absence of adequate communication between authorities, experts and local people make a great influence on effectiveness of climate mitigation policies. Corrupt, undemocratic with self-surviving values country cannot provide a successful implementation of climate mitigation policies, but there are also democratic countries which due to their values in society do not pay much attention to environmental problems. Due to the ignorance of these factors the effect of climate mitigation policies is short-lived, especially when the main mechanism of influence is subsidies and donation. For decreasing policies costs and increasing effectiveness of developed policies, prediction of how successful climate policy can be in certain country should be included in modelling of climate mitigation policies. As far as countries, due to various socio-political factors have different possibilities to implement climate mitigation policies. [9]

The Equitable Governance of Common Goods Programme [5], Investigating Observability of Complex Resource ConsumptionNetworks [4], TheEnvironmental Democracy Index [15] and Agent-based model of the Emergence of Climate Change Mitigation Action by Society [12] try to predict information exchange and its influence on "dynamic of a shared renewable resource"; appearance of climate mitigation initiatives from local citizens. Agent-based model of the Emergence of Climate Change Mitigation Action by Society based on the assumption that in the democratic countries citizens begin to initiate and demand adoption of legislative acts aimed to mitigate climate change. Key factor is growing awareness of the society about climate change.
The above-mentioned assumption can be developed:

1) If a large part of population is dissatisfied with the activity of the authorities regarding the environmental situation in the state, the risk of protests and falling confidence in the institutions of power will increase;

2) If the world community can not solve the issue of global climate change, then the number of drought, sudden floods, abnormal rise in temperature, etc. will be worse. It will lead to a rise in poverty, armed conflicts, food shortages, rising numbers of refugees, etc.

It is a clear illustration how national security of the state depends directly on ecological security. 12

\section{International Futures (IFs) model}

However, there is no one generalized concept or model which will forecast state's readiness and possibility to implement climate change mitigation policies. Partly, influence of socio-political factors on implementation of the climate change mitigation policies can be developed in International Futures (IFs) model. International Futures is an integrated assessment model, which combine knowledge from politic, environment, economic, social, cultural spheres (Fig.3). [1]

There are four developed scenarios (Economy first, Policy first, Security first, Sustainability first) and possibility to create new, due to user's interest; time horizon for

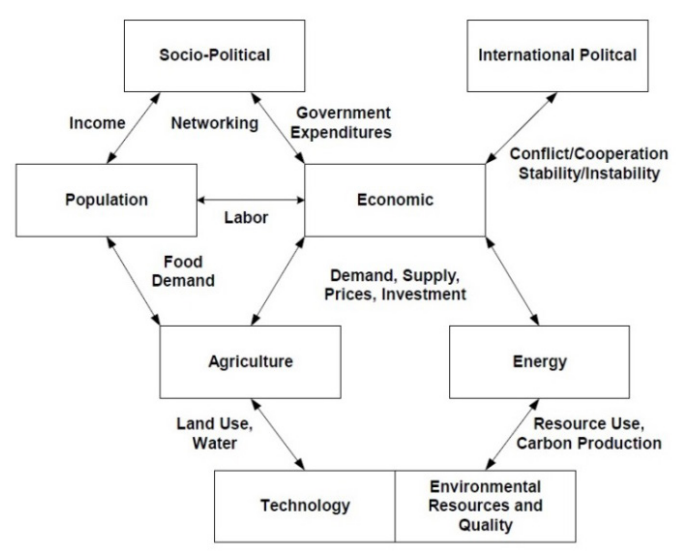

Fig. 3. Interactions within the model 


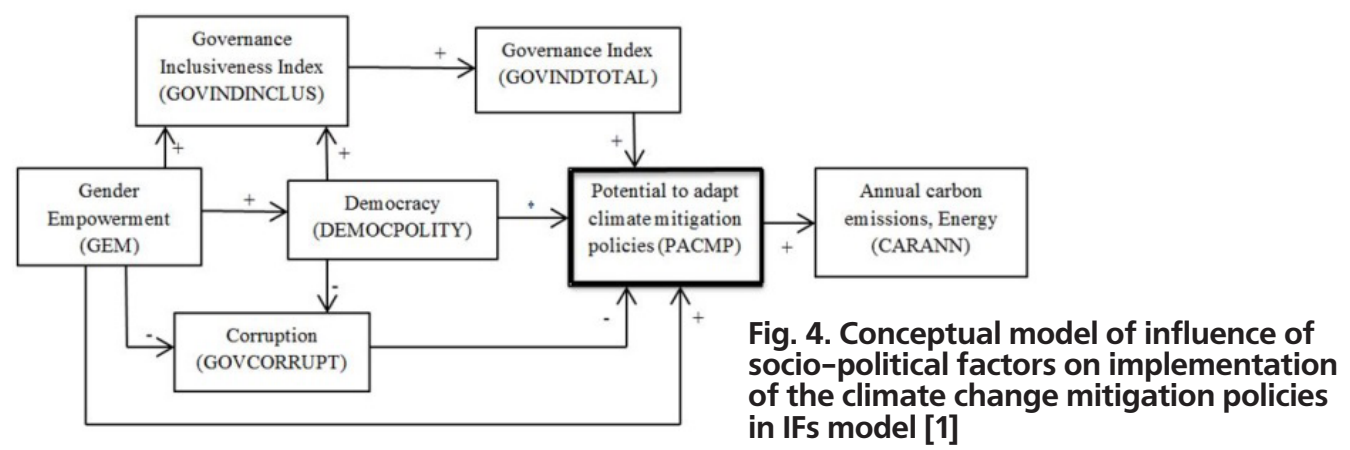

forecasts is from 2000 till 2100 years. Links between "Socio-Political" and "Environment" sub-models have not been developed yet.13 Although links can be created through creating additional indicator "Potential to adapt climate mitigation policies" (Fig. 4).

This conceptual model of influence of socio-political factors on implementation of the climate change mitigation policies in IFs model is the simplified way of introduction socio-political factors into modelling of the implementation of climate change mitigation policies in IFs model. [9]

\section{Ecological and national security of Ukraine}

Ukraine has a high level of corruption, prevalence of survival values, inefficiency of government institutions, gaps in legislation, however
Ukrainian government made Green Tariff for increasing share of renewable resources in total energy demand. [8] Socio-economical scenarios and their influence on using biomass as source of energy and decreasing of $\mathrm{CO}_{2}$ emissions were developed and modeled in project "Geospatial analysis of greenhouse gas sinks and emission in Forestry for decision making support" of Lviv Polytechnic National University. The share of fuel wood in the Ukrainian wood industry concludes $60-80 \%$ of overall wood demand. Between growth of gross domestic product (GDP) and demand of fuel wood is strong correlation (for 2003 - 2012 coefficient of correlation is 0.85 ).

The coefficients of the equation were determined using method of least squares: $y=0,14+0,85 x$. The demand of fuel wood and

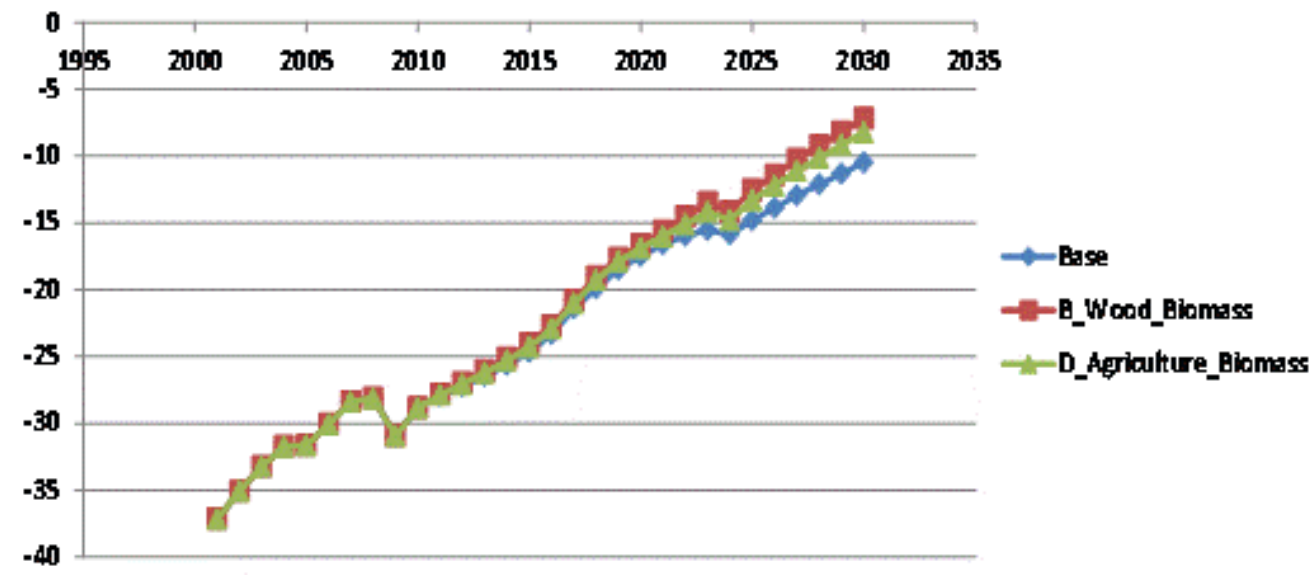

Fig. 5. Emissions of $\mathrm{CO}_{2}$ due to change of wood demand in accordance with various scenarios of socio-political development, $\mathrm{Mt} \mathrm{CO}_{2} 16$ 


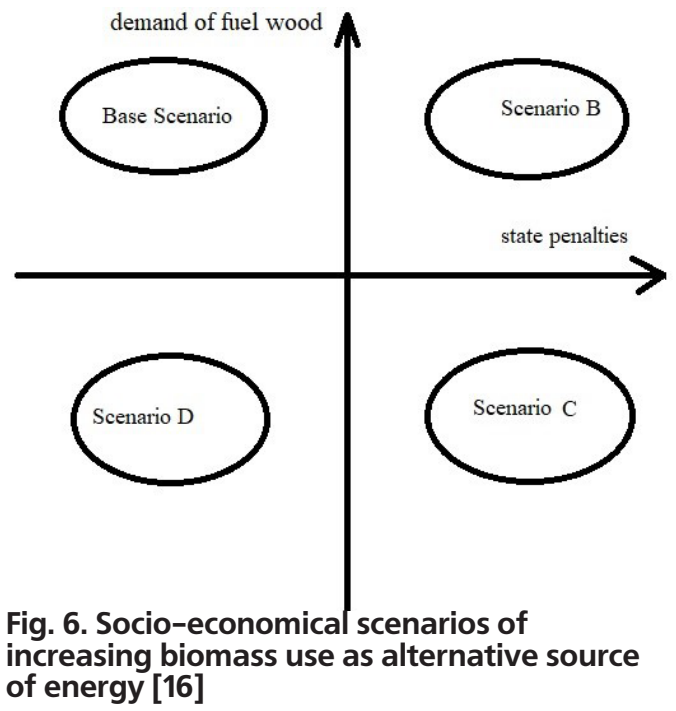

total wood demand were forecasted using data of GDP from base scenario in IFs model. In Fig. 5 illustrated emissions of $\mathrm{CO}_{2}$ due to change of wood demand in accordance with various scenarios of socio-political development $\left(\mathrm{Mt} \mathrm{CO}_{2}\right)$. [2]

Scenario are based on two uncertainties "state penalties" and "demand of fuel wood" (Fig.6). A scenario - base scenario (without change); B scenario - very optimistic (government use restraining and stimulating mechanisms); C scenario - government use only stimulating mechanisms; D scenario "agricultural state" (government stimulate development of agricultural sector).16

\section{Conclusion}

The first step of limiting the increase in global temperature to no more than 1.5 to 2 degrees Celsius are inventory of greenhouse gas and developing climate mitigation policies. But second step is to implement climate mitigation policies on national level and get result like increasing share of renewable resources in total demand, afforestation, increasing efficiency of energy use in sector of housing maintenance and utilities, decreasing energy intensity because of increasing of energy efficiency. For decreasing policies costs and increasing effectiveness of developed policies, it is necessary to consider socio-political conditions of certain countries during developing scenarios and climate mitigation policies. In project "Geospatial analysis of greenhouse gas sinks and emission in Forestry for decision making support" were developed scenarios that consider improving social sphere and national security from increasing share of renewable resources in total energy demand. Potential to adopt/implement climate mitigation policies can be estimated in IFs model because it already contains information about government, corruption and level of democracy.

\section{References}

1. Barry B. Hughes, Anwar Hossain, Mohammod T. Irfan, The structure of International Futures (IFs), University of Denver, July 2004, Working paper 2004.07.19.

2. Geospatial analysis of greenhouse gas sinks and emission in Forestry for decision making support, Chapter 6, Report, Lviv Polytechnic National University, 2014.

3. Human Activity in an Earth System Hierarchy, NCAR, 2016 Annual Report. URL: http:/ / www.nar.ucar. edu/2012/lar/nesl/iii-human-activity-earth-system-hierarchy.html

4. International Institute for Applied Systems Analysis, February 2017, 2013 YSSPer Talha Manzoor, URL: http://www.iiasa.ac.at/web/home/about/alumni/News/170213-editorial.html

5. International Institute for Applied Systems Analysis, July 2016, Equitable Governance of Common Goods, URL: http:/ / www.iiasa.ac.at/web/home/research/researchPrograms/EvolutionandEcology/ Equitable-Governance-of-Common-Goods.en.html

6. International Institute for Applied Systems Analysis, SSP Database, 2012 - 2016. URL: https://tntcat. iiasa.ac.at/SspDb

7. IPCC Workshop on Socio-Economic Scenarios, Intergovernmental Panel on Climate Change, Workshop Report, Berlin, Germany, 1-3 November 2010.

8. Law of Ukraine "About electric power". From 1998 year, №575/97 VR. URL: http:/ / zakon4.rada.gov. ua/laws/show/575/97-\%D0\%B2\%D1\%80 . 
9. Okhremchuk I.A. Creating a linkage between "Environment" and "Socio-Political" blocks in the International Futures model, 6th International Youth Science Forum "Litteris et Artibus", 8th International Academic Conference of Young Scientists "Computer Science and Engineering 2016" (CSE-2016)

10. Resolution "Transforming our world: the 2030 Agenda for Sustainable Development". The General Assembly. Seventieth session. From 25 September 2015

11. Scientists discuss the 1.5C limit to global temperature rise, CarbonBrief. URL: https://www.carbonbrief. org / scientists-discuss-the-1-5c-limit-to-global-temperature-rise

12. Sebastiaan Greeven. The Emergence of Climate Change Mitigation Action by Society: An Agent-Based Scenario Discovery Study/ Sebastiaan Greeven, Oscar Kraan , mile J.L. Chappin, Jan H. Kwakkel, The Journal of Artificial Societies and Social Simulation, Volume 19, Issue 3, June 2016. URL: http://jasss. soc.surrey.ac.uk/19/3/9.html

13. The Sustainable Development Agenda, Sustainable Development Goals. URL: http://www.un.org/sustainabledevelopment/development-agenda/

14. UN Sustainable Development Summit (25-27 September), United Nation Information center Canberra, URL: http:/ / un.org.au/2015/09/02/un-sustainable-development-summit-25-27-september /

15. World Resources Institute, 2015, Release: Major New Index Ranks Environmental Democracy in 70 Countries. URL: http://www.wri.org/news/2015/05/release-major-new-index-ranks-environmental-democracy-70-countries

16. Okhremchuk I.A. The Conceptual Model of Socio-political Factors' Influence on Implementation of Climate Mitigation Policies in the Forestry Sector, Scientific Bulletin of Ukrainian National Forestry University, No: 26.7, p.:416-422

\section{АНОТАЦІЯ}

I. А. Охремхук . Моделювання політик пом'якшення зміни клімату з урахуванням рівнем соиіально-політичного розвитку держави//Біоресурси і природокористування - 2017. - 9, №3-4. - C.34-39.

Кіотсъкий протокол, Паризъка угода та кониепиія сталого розвитку були розроблені з метою вирішення глобальної екологічної кризи та недопущення збільшення температури Землі більше, ніж на 1,5-2 градуси Цельсія. Екологічна безпека має безпосередній вплив на начіональну безпеку держави. Якио міжнародна спільнота не знайде спосіб подолати глобальну екологічну кризу, то ие призведе до зростання рівня бідності, дефіииту продовольства, збільшення кількості конфліктів та біжениів. Для моделювання і прогнозування майбутніх викидів парникових газів, вибору оптимальної політики скорочення викидів парникових газів у окремих секторах економіки, аналізу впливу парникових газів на життя $i$ здоров'я людей використовуються моделі інтегральної оуінки. Однак проиес моделювання політик пом'якшення зміни клімату повинен включати у себе також можливості крайн успішно впроваджувати иі політики у начіональні господарства. Тобто корумпована держава із низьки рівнем демократї, превалюванням иінностей виживання та рівноправ'ям має низкі можливості для успішнӧ реалізаиї політики пом'якшення наслідків зміни клімату.

Ключові слова: сиенарї МГЕЗК, Кіотсъкий протокол, Паризъка угода, кониепиія сталого розвитку, політики пом'якшення зміни клімату, моделі інтегрованої очінки, імплементачія політик пом'якшення зміни клімату

\section{АННОТАЦИЯ}

И. А. Охремчук Моделирование политик последствий воздействия изменения климата с учетом уровня соииально-политического развития государства//Биоресурсы и природопользование. - 2017. 9, №3-4. - C.34-39.

Киотский протокол, Парижская соглашение $и$ конщепчия устойчивого развития были разработаны с иелью решения глобального экологчческого кризиса и ограничения увеличения температурь Земли не более чем на 1,5-2 градуса Цельсия. Экологическая безопасность имеет непосредственное влияние на наииональ ную безопасность государства. Если международное сообщество не найдет способ преодолеть глобальньй экологический кризис, то это приведет к росту уровня бедности, дефииита продовольствия, увеличение колиества конфликтов и бежениев. Для моделирования и прогнозирования будуших въібросов парниковых газов, выбора оптимальнй политики сокрашения выбросов парниковых газов в отдельных секторах экономики, анализа влияния парниковъхх газов на жизнь и здоровъе людей испольуются модели интегральной оценки. Однако, процесс моделирования политик смягчения изменения климата должен включать в себя также и возможности стран успешно внедрять эти политики в национальные хозяйтва. То есть коррумпированное государство с низким уровнем демократии и равнотравия, превалированием иенностей выживания имеет низкие возможсности для успешной реализаиии политики смягчения последствий изменения климата.

Ключевые слова: сценарии МГЭИК, Киотский протокол, Парижское соглашение, кониепиия устойчивого развития, политики смягчения изменения климата, модели интегрированной оченки, имплементаиия политик смягчения изменения климата 